\title{
The Matthean Jesus' surprising instruction to obey the teachers of the Law and Pharisees
}

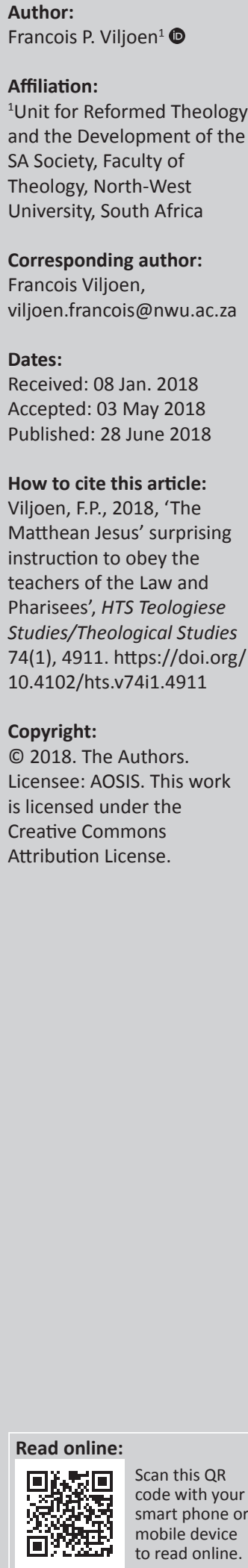

Jesus' instruction to the crowds in Matthew 23:3 to obey and do everything the teachers of the Law and the Pharisees tell them comes as a surprise. It is the only case in Matthew where the words of the Jewish leaders are seemingly portrayed in a positive light. If this portrayal indeed is positive, it seems to stand in tension with how Matthew construes these leaders and their teachings in the rest of the gospel (e.g. Mt 5:20; 15:3-6, 15:14; 16:11-12). Jesus' positive remark furthermore seemingly stands in contrast with Matthew 28:20, where Jesus claims all authority to himself and instructs his disciples to teach all the nations to obey everything he has commanded them. The question therefore arises as to how this seemingly positive reference of Jesus, which apparently stands in contrast with Jesus' criticism in the rest of the gospel, should be interpreted. In answering this question, an intra-textual approach is followed.

\section{Introduction}

The instruction of Jesus to the crowds in Matthew 23:3 to obey and do everything the teachers of

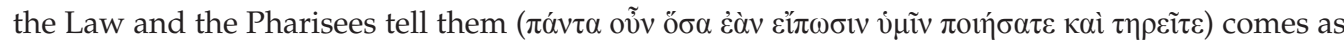
a surprise. It is the only case in Matthew where the words of the Jewish leaders are seemingly portrayed in a positive light. If this portrayal indeed is positive, it seems to stand in tension with how Matthew construes these leaders and their teachings in the rest of the gospel (e.g. Mt 5:201; $\left.15: 3-6,{ }^{2} 15: 14 ;{ }^{3} 16: 11-12\right)^{4}$. Jesus' positive remark furthermore seemingly stands in contrast to Matthew 28:20, ${ }^{5}$ where Jesus claims all authority to himself and instructs his disciples to teach all the nations to obey everything he has commanded them. The wording in Matthew 23:3 and Matthew 28:20 is so similar that some kind of relationship between these verses seems probable. Furthermore, the Jewish leaders receive very harsh criticism in the verses that follow in Matthew 23:3. How is it then possible that Jesus encourages the crowds and his disciples to adhere and do everything the teachers of the Law and the Pharisees tell them?

Does Jesus at this stage endorse their teachings of the Torah and their halakha, and by doing so contradict himself? Should this statement in the gospel be regarded as a remnant of the preMatthean tradition that the author inattentively incorporated into the text, though it is out of keeping with the rest of the gospel? Does it belong to a pre-Easter sentiment within the Jesusmovement before the development of their critical view on Pharisaic Judaism? Is the phrase, 'all their teachings' an exaggeration so that Jesus is actually only referring to part of their teachings? Does Jesus make an ironic pronouncement? Does Jesus insinuate that the Jewish teachers of the Law are inconsistent with their teachings, and that their teachings are confusing? Does it demonstrate that the Jewish teachers are ignorant of their own teachings, which are indeed correct? Do the teachers teach the correct stuff, though their conduct contradicts their teachings? Does Jesus illustrate that their own teachings condemn them? Does Jesus differentiate between their words directly from the Torah and from their halakha? Or should we accept that the halakhic traditions laid down by the Pharisees remained valid and provided the Matthean community with practical ways to obey the Torah, and that Jesus only criticises their neglect of the 'weightier matters' of the Law?

1.Matthew 5:20: 'For I tell you that unless your righteousness surpasses that of the Pharisees and the teachers of the law, you wil certainly not enter the kingdom of heaven' (see Viljoen 2013).

2.Matthew 15:3-6: Jesus replied, 'And why do you break the command of God for the sake of your tradition? ... Thus you nullify the word of God for the sake of your tradition' (see Viljoen 2014).

3.Matthew 15:14: 'They are blind guides. If the blind lead the blind, both will fall into a pit'.

4.Matthew 16:11-12: 'Be on your guard against the yeast of the Pharisees and Sadducees. Then they understood that he was not telling them to guard against the yeast used in bread, but against the teaching of the Pharisees and Sadducees'.

5.Matthew 28:18-20: 'Then Jesus came to them and said, "All authority in heaven and on earth has been given to me. Therefore go and make disciples of all nations, baptizing them in the name of the Father and of the Son and of the Holy Spirit, and teaching them to obey everything I have commanded you"', 
To choose between these suggestions is not simple, and there may even be more options for interpreting these words of Jesus. This investigation follows an intra-textual approach to reach an informed conclusion on the meaning of this statement. The intra-textual approach implies that this statement would be read with consideration of the context provided by similar statements in the same document and its setting within the immediate development of the plot of this gospel. Such an intra-textual setting clarifies the development of Matthew's argument. The interpretation is thus constructed by making use of cues from the text itself.

\section{The context of Matthew 23}

Jesus' pronouncement on the teachings of these leaders opens the last of Matthew's five great discourses in the gospel. ${ }^{6}$ The symmetry between the first and last discourses is noteworthy and they frame Jesus' public ministry in Matthew. While the first great discourse opens with blessings ( $\mu \alpha \kappa \alpha$ ó

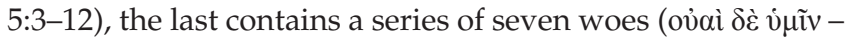
Mt 23:13-32). These two discourses are of similar length. Both of these sermons are associated with a mountain and Jesus takes the seated position of a teacher (Mt 5:2 and 24:3) (Gundry 1994:453; Osborne 2010:831). Jesus is presented as the new Moses. As Moses came down the mountain to present the Law, Jesus went up the mountain to teach the Law authoritatively (Sermon on the Mount), and to expose false and hypocritical practices regarding the Law on Mount Olives (Mt 23-25).

While conflict between Jesus and the religious leaders, who also became political-societal leaders, is central throughout Matthew's plot, $^{7}$ the conflict intensifies significantly in the final discourse (Keener 1999:536; Repschinski 2000). In this way, Matthew 23 prepares the reader for the passion narrative where Jesus is cruelly rejected by the Jewish leaders (Davies \& Allison 2004:262).

Luz (1968:96) goes as far as remarking: 'With its woes and its unjust wholesale judgement about scribes and Pharisees, Matthew 23 is the unloveliest chapter in the gospel', a sentiment Viviano (1990:3) shares. Carter (2000b:66) describes it as 'the bleakest spot' in Matthew's gospel. Esler (2015:39-59) is of the opinion that this challenging text is best understood in terms of intergroup conflict between a branch of the Christmovement and a Judean outsider group. He investigates the passage in terms of social identity theory and describes Matthew 23 as one of the most extreme forms of intergroup conflict. He opines that this passage is the product of the

6.The five great discourses in the gospel are: the Sermon on the Mount (Mt 5-7), the missionary charge (Mt 10:5-42), the parables discourse (Mt 13:3-52), instruction to the community (Mt 18:3-35) and the woes and eschatological discourse ( $\mathrm{Mt}$ 23-25) (Riesner 1978:177-178). Combrink (1983:61-90) identifies a chiastic structure between these discourses: the Sermon on the Mount (Mt 5-7) is paralle to the woes and the eschatological discourse (Mt 23-25). The missionary charge (Mt 10) is parallel to the community discourse (Mt 18). The parables discourse (Mt 13) is framed by the above-mentioned parallels. The woes and the eschatological discourse (Mt 23-25) approximately balance the first discourse, the Sermon on the Mount (Mt 5-7) (Keener 1999:535; Osborne 2010:831; Viviano 1990:9).

7.Kingsbury (1995:169) regards these leaders more central to Matthew's plot than the Kingsbury (1995:169) regards these leaders more central to Matthew's plot than the opines that this may be because the successors of the teachers of the Law and the Pharisees were the main Jewish opposition that the addressees faced in SyriaPalestine. evangelist and not of the historical Jesus, as he regards the polemic as untypical of the historical Jesus (Esler 2015:56). Kümmel (1967:146-147) remarks that the zealous polemic in Matthew 23 distorts the reality and spirit of Jesus.

The continuous theme of judgement is significant and particularly intense in this final discourse. Obviously, this should therefore be taken into account with the interpretation of Matthew 23:3.

In honour and shame societies, as in New Testament times, it was a common phenomenon to challenge the honour of an opponent and to respond with an equal challenge in return (De Silva 2004:128-130; Malina \& Rohrbauch 2003:42; Witherington 2013:47). Such a challenge had to be played in public to be effective in gaining honour or imposing shame. In the Matthean text, the religious leaders' public challenges of Jesus' authority to teach (Mt 21:23-22:46) are balanced by Jesus' public response with his pronouncements of judgement on the Pharisees and Jerusalem (Mt 23:1-24:2).

The intensity of the Matthean controversy becomes apparent when considering the probable source material for Matthew 23:1-39. It seems that Mark 12:38-40 formed the impetus for Matthew 23:1-39 (Davies \& Allison 2004:266). If this is the case, Matthew developed a lengthy polemic of 39 verses based on a mere 3 verses in Mark (see Table 1).

\section{Criticism of the teachers of the Law and Pharisees (MT 23:1-39)}

Jesus' seemingly positive pronouncement on the words of the teachers of the Law and Pharisees (Mt 23:3) falls in the first of three sections of Matthew 23, each addressing a different audience (Osborne 2010:832):

- In Matthew 23:1-12, Jesus warns the crowds and the disciples against the teachers of the Law and the Pharisees.

- In Matthew 23:13-36, he addresses the teachers of the Law and the Pharisees directly in his criticism.

- In Matthew 23:37-39, he addresses Jerusalem with sorrow lamenting its immanent judgement.

The section is concluded with the pronouncement of a distressing judgement over the temple (Mt 24:1-2). ${ }^{8}$

\section{Addressing the crowds on the hypocrisy of the teachers of the Law and the Pharisees (Mt 23:1-12)}

In his criticism of the teachers of the Law and the Pharisees in Matthew 23:1-12, Jesus addresses the crowds who have heard how these Jewish religious leaders had challenged

8. Newport (1995:76-79) proposes that the source for Matthew 23:2-31 is a pre-70 CE Jewish-Christian tract, and that Matthew 23:32-39 is a later redaction. He argues that Matthew 23:2-31 exhibits an intra muros setting, while he assumes that that Matthew 23:2-31 exhibits an intra muros setting, while he assumes that Matthew writes from an extra muros position. He argues that Matthew 23:2-31 describes customs and practices of first-century Jews, which indicates an intraJewish debate. He regards the Sitz im Leben of this section similar to that of the Sermon on the Mount and as being different to the rest of the gospel (Newport 1995:157). In such a way, Newport escapes the difficulty to fit this troublesome passage within the gospel as a whole. However, as difficult it is to explain, this passage does form part of the text and needs interpretation. 
TABLE 1: Matthew's development of Mark's polemic.

\begin{tabular}{|c|c|}
\hline Mark 12:38-40 & Matthew 23:1-39 \\
\hline As he taught, Jesus said (Mk 12:38a) & $\begin{array}{l}\text { Then Jesus said to the crowds and to his } \\
\text { disciples (Mt 23:1) }\end{array}$ \\
\hline $\begin{array}{l}\text { Watch out for the teachers of the Law } \\
\text { (Mk 12:38b) }\end{array}$ & $\begin{array}{l}\text { So you must be careful to do everything } \\
\text { they tell you. But do not do what they } \\
\text { do, for they do not practice what they } \\
\text { preach (Mt 23:3) }\end{array}$ \\
\hline $\begin{array}{l}\text { They like to walk around in flowing robes } \\
\text { (Mk 12:38c) }\end{array}$ & $\begin{array}{l}\text { Everything they do is done for people to } \\
\text { see: They make their phylacteries wide } \\
\text { and the tassels on their garments long } \\
\text { (Mt 23:5) }\end{array}$ \\
\hline $\begin{array}{l}\text { and be greeted with respect in the } \\
\text { marketplaces ( } \mathrm{Mk} 12: 38 \mathrm{~d})\end{array}$ & $\begin{array}{l}\text { they love to be greeted with respect in } \\
\text { the marketplaces and to be called } \\
\text { 'Rabbi' by others (Mt 23:7) }\end{array}$ \\
\hline $\begin{array}{l}\text { and have the most important seats in the } \\
\text { synagogues (Mk 12:39a) }\end{array}$ & $\begin{array}{l}\text { they love the most important seats in } \\
\text { the synagogues (Mt 23:6b) } \dagger\end{array}$ \\
\hline $\begin{array}{l}\text { and the places of honour at banquets } \\
\text { (Mk 12:39b) }\end{array}$ & $\begin{array}{l}\text { the place of honour at banquets } \\
\text { (Mt 23:6a) }\end{array}$ \\
\hline \multicolumn{2}{|l|}{ They devour widows' houses (Mk 12:40a) } \\
\hline $\begin{array}{l}\text { and for a show make lengthy prayers } \\
\text { (Mk 12:40b) }\end{array}$ & Cf. Matthew 23:5 \\
\hline $\begin{array}{l}\text { These men will be punished most severely } \\
\text { ((Mk 12:40c) }\end{array}$ & $\begin{array}{l}\text { Series of seven 'Woe to you ...' } \\
\text { pronouncements (Mt 23:13-14, 15, } \\
16-22,23-24,25-26,27-28,29-32 \text { ) } \\
\text { 'You snakes! You brood of vipers! How } \\
\text { will you escape being condemned to } \\
\text { hell? (Mt 23:33) }\end{array}$ \\
\hline \multicolumn{2}{|c|}{$\begin{array}{l}\text { From this comparison, it is clear that Jesus' criticism in Matthew (Mt } 23: 1-24: 2)^{9} \text { is much } \\
\text { more extensive and intense than in Mark. }\end{array}$} \\
\hline & \\
\hline
\end{tabular}

respectful greetings in the marketplaces) (Lk 11:43).

Jesus, and how he time and again refuted these challenges and wisely emerged as victor (Mt 22:22, 33, 34, 46). Jesus' profile is that of a wise and superior teacher in contrast to the teachers of the Law and Pharisees who proposed to be the ultimate interpreters and teachers of the Law.

Jesus tells the crowds what the teachers of the Law and the Pharisees do (Mt 23:1-7) and then proceeds to talk about what his disciples should do instead (Mt 23:8-12). It seems that the main idea is to contrast the pride and hypocrisy of these leaders with the humility and servanthood required from Jesus' followers (Osborne 2010:833).

\section{The hypocritical conduct of the teachers of the Law and Pharisees (Mt 23:1-7)}

In the first part of his criticism of the teachers of the Law and the Pharisees, Jesus addresses the crowds and his disciples, $\tau$ tó $\varepsilon$

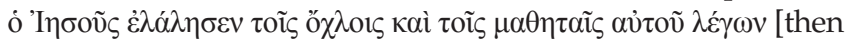
Jesus said to the crowds and to his disciples] (Mt 23:1), as in the Sermon on the Mount (Mt 5:1-2). In contrast to the Sermon on the Mount where these words open the blessings and wise instruction of Jesus, the opening words in Matthew 23 form the introduction of the woes and stern polemic to follow.

The criticism is twofold (Davies \& Allison 2004:264; Talbert 2010:256). Firstly, Jesus depicts the hypocritical teaching and conduct of the religious leaders (Mt 23:2-4) and secondly, their desire for public acclaim (Mt 23:5-7) (see Table 2).

Jesus remarks that the teachers of the Law and the Pharisees

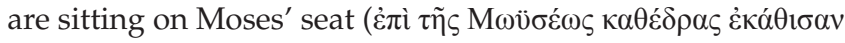

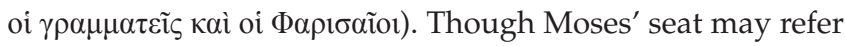
to a physical chair, it is most probably used metaphorically to

9.This extended polemical discourse is unique to Matthew, with only a few parallels: Mt 23:4 // Lk 11:46; Mt 23:6-7a // Mk 12:38-39 and Lk 20:46-47; and Mtt 23:12 // Lk 14:11 and 19:14.
TABLE 2: The pretence of the religious leaders.

\begin{tabular}{|c|c|}
\hline Greek text & English translation \\
\hline \multicolumn{2}{|c|}{ Matthew 23:2-4: Hypocritical teaching and conduct } \\
\hline 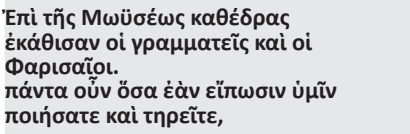 & $\begin{array}{l}\text { The teachers of the Law and the } \\
\text { Pharisees sit in Moses' seat. } \\
\text { So you must be careful to do everything } \\
\text { they tell you. }\end{array}$ \\
\hline 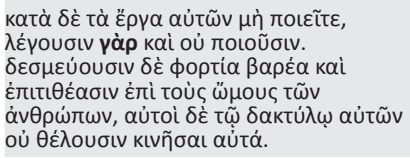 & $\begin{array}{l}\text { But do not do what they do, } \\
\text { for they do not practice what they preach. } \\
\text { They tie up heavy, cumbersome loads and } \\
\text { put them on other people's shoulders, but } \\
\text { they themselves are not willing to lift a } \\
\text { finger to move them. }\end{array}$ \\
\hline \multicolumn{2}{|l|}{ Matthew 23:5-7: Desire for public acclaim } \\
\hline 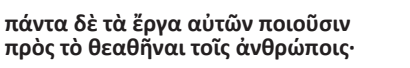 & $\begin{array}{l}\text { Everything they do is done for people to } \\
\text { see }\end{array}$ \\
\hline 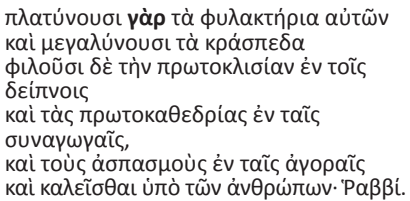 & $\begin{array}{l}\text { for they make their phylacteries wide and } \\
\text { the tassels on their garments long; } \\
\text { they love the place of honour at banquets } \\
\text { and the most important seats in the } \\
\text { synagogues; } \\
\text { and to be greeted with respect in the } \\
\text { marketplaces } \\
\text { and to be called 'Rabbi' by the people. }\end{array}$ \\
\hline
\end{tabular}

refer to persons who are considered to have teaching authority. ${ }^{10}$ Powell (1995:419-435) lists 10 options of what the phrase may refer to and concludes that it most probably refers to the authority of those who controlled access to the Torah scrolls and who could read and interpret them for the people. They occupied a powerful social and religious position in a world where most people were illiterate and

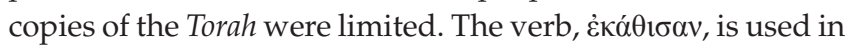
the aorist, which most probably should be read as gnomic, probably referring to the general claim for authority as made by these leaders (Osborne 2010:835). The Pharisees claimed to be Moses' successors and therefore had the presumption that they were the official interpreters of the Torah who could speak with ultimate authority (Davies \& Allison 2004:268; Gundry 1994:454; Keener 2002:103; Viviano 1990:11). However, the statement can also simply mean that they were the only ones who had access to the written Torah (Powell 1995:435).

It seems obvious that Jesus' instruction should be read against the previous set of challenges set by these religious leaders who were trying to expose Jesus' lack of authority to teach (Mt 21:23-22:46). The religious leaders presume to have the ultimate authority to read, interpret and teach the Torah.

Jesus' instruction to obey the words of the teachers of the Law and the Pharisees can be interpreted in differing ways. The one way would be that Jesus ironically refers to their own presumption of being the authoritative instructors of the Law $^{11}$ (Mason 1990:363-381). Based on their presumption, Jesus then proceeds to criticise them. If they indeed are as authoritative as they presume to be, the crowds and his disciples should carefully do whatever the religious leaders

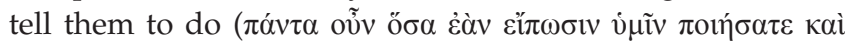

10.Not all Pharisees were authoritative teachers of the Law. Matthew frequently lumps them together. It seems that in Matthew's experience they formed a unified Jewish front of confrontation (Davies \& Allison 2004:267).

11.Josephus mentioned that the general populace regarded the Pharisees as the most skilful in interpreting the Jewish laws (Ant 17:41; Jews Wars 1.110; 2.162; Life 191). However, he lamented this fact, as he accused them of not always doing this with pure motives (Talbert 2010:257). 


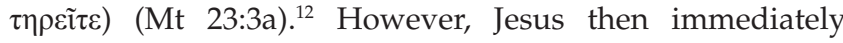
continues by warning the crowds and disciples not to do what the religious leaders do, because they do not practice

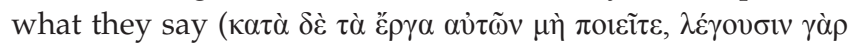

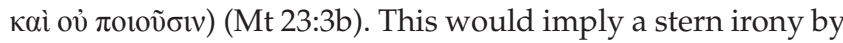
Jesus. The words $\kappa \alpha \tau \grave{\alpha} \delta \grave{\varepsilon}$ emphasises the contrast and irony.

This verse exhibits Matthew's love for parallelisms and his emphasis on the fact that there should be consistency between words and actions (Gundry 1994:454), which is lacking in the case of these leaders. In parallel form, Matthean Jesus states the paradox between their presumed positive teachings and their negative conduct.

Presumed positive teaching:

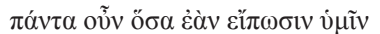

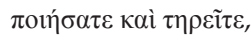

Negative conduct:

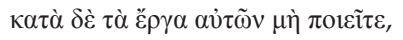

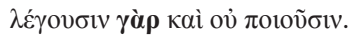

This parallel seems to be a reflection on the parable of the disobedient son in Matthew 21:28-32. Therefore, it seems as if the imperative of Matthew 23:3a is meant ironically. Though the religious leaders claim to have the authority to interpret the Torah accurately, their lives testify to the opposite. Their teachings are insincere and untrustworthy. This results in a harsh accusation of the inconsistency of these teachers. The Matthean Jesus continues to criticise the distorted teachings of the teachers of the Law and the Pharisees and their inability to keep the Law correctly, as they neglect the Law for the sake of their traditions (e.g. Mt 14:3). Jesus thus criticises their claim to be the most skilful interpreters of the Law by pointing out that their conduct reveals the opposite.

However, Gundry (1994) and Powell (1995) offer an alternative interpretation of the verse that should be considered. Gundry (1994:455) argues that Jesus' pronouncement means that as long as the teachers of the Law are sitting on the seat of Moses, they are purely reading the Law of Moses (the written Torah) and not their interpretive traditions (halakha). In such circumstances people should obey them. However, one should not follow their conduct, as their conduct does not correlate with their reading. Powell (1995:431-433) proposes a similar argument. He argues that when Jesus mentions that the Pharisees speak ( $\varepsilon i \pi \omega \sigma v v$ and

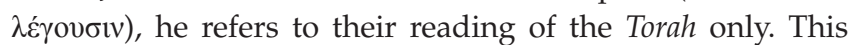
action of the Pharisees Jesus commends. However, when Jesus mentions their works ( $\tau \grave{\alpha}$ है $\rho \gamma \alpha)$ and what they do

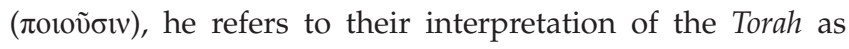
reflected in their halakha. Their interpretations reveal a skewed understanding of the Torah. They do not understand the Torah they so correctly cite. Jesus therefore warns his disciples not to follow their halakha.

12.This command of Jesus echoes the wording of Deuteronomy 17:11 where Moses instructs the Jewish people to adhere to the legal rulings of the priests and the judges of their generations (Rabbinowitz 2003:432).
TABLE 3: Jesus' disapproval of the teaching and conduct of the teachers of the Law and Pharisees.

\begin{tabular}{|c|c|}
\hline Greek text & English translation \\
\hline \multicolumn{2}{|l|}{ General indictment } \\
\hline 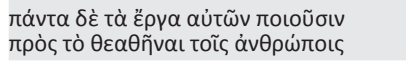 & $\begin{array}{l}\text { Everything they do is done for people to } \\
\text { see: }\end{array}$ \\
\hline \multicolumn{2}{|l|}{ Example 1} \\
\hline 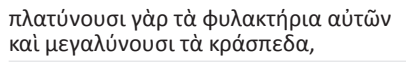 & $\begin{array}{l}\text { They make their phylacteries wide and the } \\
\text { tassels on their garments long; }\end{array}$ \\
\hline \multicolumn{2}{|l|}{ Example $2 \mathrm{a}$ and $\mathrm{b}$} \\
\hline 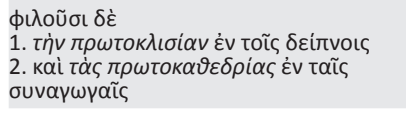 & $\begin{array}{l}\text { they love } \\
\text { 1. the place of honour at banquets } \\
\text { 2. and the most important seats in the } \\
\text { synagogues; }\end{array}$ \\
\hline \multicolumn{2}{|l|}{ Example $3 a$ and $b$} \\
\hline 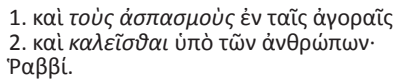 & $\begin{array}{l}\text { 3. and to be greeted with respect in the } \\
\text { marketplaces } \\
\text { 4. and to be called 'Rabbi' by others. }\end{array}$ \\
\hline
\end{tabular}

This string of thought continues in the next verse which could be regarded as support of the argument of Gundry and Powell, although it can also be regarded as an ironic exposure of the assumed authoritative teaching of these Jewish leaders. The Matthean Jesus continues his argument by illustrating verses 2-3 in an ironic manner. In Matthew 23:4, Jesus criticises the teachers of the Law and the Pharisees for compiling multiple obligations to the Law with their own interpretations, making it extremely difficult to bear, and Jesus accuses them of not adhering to their own obligations:

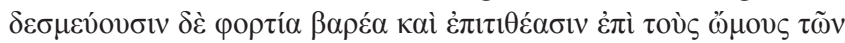

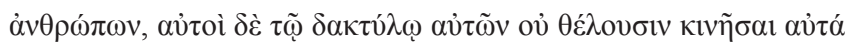
[they indeed tie up heavy, cumbersome loads and put them on other people's shoulders, but they themselves are not willing to lift a finger to move them]. The Matthean Jesus once again uses $\delta \dot{\varepsilon}$ to stress the antithesis. The image implies a heavy and burdensome yoke ${ }^{13}$ being laid on the shoulders of the people who they teach. This imagery recalls the light yoke and the easy commandments of Jesus in Matthew 11:30 in stark contrast with the burden implied by the teachings of the Jewish teachers of the Law (Esler 2015:44; Gundry 1994:455). The Jewish teachers, who assume to be superior teachers of the Law, turn the Law into a crushing and unbearable burden with their skewed interpretations.

In Matthew 23:5-7, Jesus proceeds to depict the teachers of the Law and Pharisees as people who do things because of wrong motives (Talbert 2010:257). In this depiction, Jesus not only refers to their interpretation of the Torah, but indeed to their overall insincere conduct. Matthew's Jesus starts off with a general indictment, followed by a series of examples (see Table 3).

The general indictment is similar to what the Jewish leaders are accused of in Matthew 6:1-6. ${ }^{14}$ It also echoes what is written in b. Sotah $22 \mathrm{~b}$ in a section labelled as 'The Plagues of the Pharisees'. In the rubric 'There are seven types of

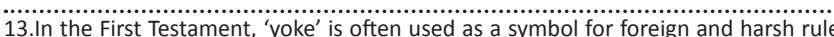
(e.g. Gn 27:40; 1 Ki 12:4-14). The release of the foreign yoke implies freedom and forgiveness (Is 9.3. 10:27). During the Second Temple Period, the term yoke was forgiveness (Is $9: 3 ; 10: 27$ ). During the Second Temple Period, the term yoke was commonly used for the instruction of the Torah (e.g. 2 En 34:1-2; 2 Apoc Bar 4:13 cf. Ac 15:10 and GI 5:1; cf. Deines 2008:67; Hagner 1993:324; Oliver 2013:85). In Sirach $6: 18-31$ and $51: 23-27$, the terms 'wisdom', 'law' and 'yoke' are linked
together. The yoke of wisdom is the instruction of the law.

14.Matthew 6:1-4: 'Be careful not to do your acts of righteousness before men, to be seen by them ... do not announce it with trumpets ... to be honoured by men ....' 
Pharisees', one of the types is described as people who perform religious duties with unworthy and pretentious motives (Talbert 2010:257). Within their honour and shame society, they sought honour through affirmation by society (cf. De Silva 2004:125; Keener 2002:104). Jesus radically rejects this prevailing mode of conduct that was typical of this ancient Mediterranean society.

Jesus' accusation is followed by a series of examples of what they do (Mt 23:5-7):

- They make their phylacteries wide and the tassels on their garments long.

- They love the place of honour at banquets and the most important seats ${ }^{15}$ in the synagogues.

- They love to be greeted in the market places and to have men call them 'Rabbi'.

From this text, it seems that much of the conflict between the Matthean community and the religious leaders was about the conduct of seeking honour along with public recognition, both with the teaching (halakha) as well as the conduct of the religious leaders (Davies \& Allison 2004:275; Keener 2002:104). Matthew 23:1-7 provides a vigorous polemic portrait of the vanity of the Pharisees and the teachers of the Law. Criticism of their teaching role is pertinent, as Jesus accuses them of their fixation on attracting honour in their teaching roles as they strive towards being called 'Rabbi' (Esler 2015:46). They taught with wrong motives in mind.

\section{What the disciples should do instead (Mt 23:8-12)}

In contrast to the vanity of the Pharisees and teachers of the Law in Matthew 23:1-7, Jesus proceeds to set out the antithetical behaviour required of discipleship, with an

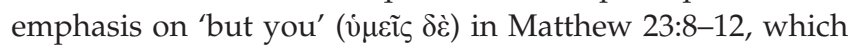
reads as a small community rule on humility (Davies \& Allison 2004:265). Wiefel (1998:397) opines that this passage is probably based on a kleine Gemeinderegel from tradition. This rule as cited in the following table signifies a contrast in community values between that of the Pharisees and teachers of the Law, and that of the followers of Jesus (see Table 4).

These guidelines remind of Matthew 18:1-4 ${ }^{16}$ and 20:25-28,17 where humility is mentioned as the basic premise of being a disciple. The contrast between عĩ [one] and $\pi \dot{\alpha} v \tau \varepsilon \varsigma$ [all] is striking. The Matthean Jesus emphasises equality of 'all' and subjection to 'one', meaning Jesus with his teaching authority (Gundry 1994:457). The disciples are warned not to claim being called 'Rabbi', 'father' or 'teacher', which would signify superior ranking among inferiors (Keener 2002:104). They are all equal $\alpha \delta \varepsilon \lambda \varphi o i$ [brothers]. This warning is summed up with the saying: 'For whoever exalts himself will be humbled, and whoever humbles himself, will be exalted'

15.The seat of honour in the synagogue could refer to the seat of Moses (Mt 23:2) (Viviano 1990:11).

16.Matthew 18:1-4: 'Who is the greatest in the kingdom of heaven? ... Therefore, whoever humbles himself like this child is the greatest in the kingdom of heaven'.

17. Matthew 20:25-28: ... whoever want to become great among you, must be your servant, and whoever wants to be first must be your slave - just as the Son of Man did not come to be served, but to serve, and to give his life as ransom to many.
Table 4: Community rule for Jesus' disciples.

\begin{tabular}{|c|c|}
\hline Greek text & English translation \\
\hline 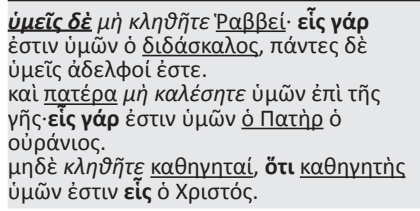 & $\begin{array}{l}\text { But you are not to be called 'Rabbi,' for } \\
\text { you have one Teacher, and you are all } \\
\text { brothers. } \\
\text { And do not call anyone on earth 'father, } \\
\text { for you have one Father, and he is in } \\
\text { heaven. } \\
\text { Nor are you to be called instructors, for } \\
\text { you have one Instructor, the Messiah. }\end{array}$ \\
\hline 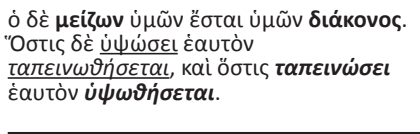 & $\begin{array}{l}\text { The greatest among you will be your } \\
\text { servant. } \\
\text { For those who exalt themselves will be } \\
\text { humbled, and those who humble } \\
\text { themselves will be exalted. }\end{array}$ \\
\hline
\end{tabular}

(Mt 23:12). The passive voice implies divine action and the future, probably the last judgement (Gundry 1994:459). Clearly, the Matthean Jesus challenges the teachings, positions and conduct of the teachers of the Law and the Pharisees and prescribes alternative community values (Esler 2015:48). The injunction in verse 8 not to be called 'Rabbi' follows directly after the accusation of the teachers of the Law and Pharisees who desire to be called 'Rabbi's', which would imply holding authoritative teaching roles. Again Jesus ironically denounces their self-acclaimed teaching positions.

The Matthean Jesus then states that in his community members should not strive to be called $\kappa \alpha \theta \eta \gamma \eta \tau \alpha i$ [instructors]

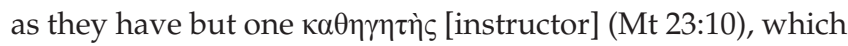

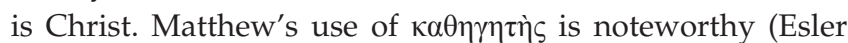
2015:49). These two appearances of the word are unique to the New Testament and do not occur in the Septuagint. France (2007:864) and Viviano (1990:12) demonstrate that this word is used for teachers in the sense that they show the way

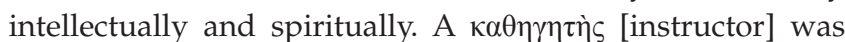
regarded of a higher rank than an ordinary $\delta 1 \delta \alpha ́ \sigma \kappa \alpha \lambda o \varsigma$ [teacher]. With his final commission in Matthew 28:18-20, Jesus instructs the 11 to teach his commandments, strongly

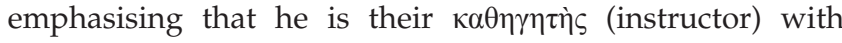
ultimate authority.

\section{Addressing the teachers of the Law and the Pharisees (Mt 23:13-36)}

In Matthew 23:13-36, Jesus addresses the teachers of the Law and Pharisees, which forms the second part of Matthew 23 (Talbert 2010:258). This address consists of a series of seven

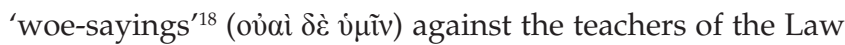

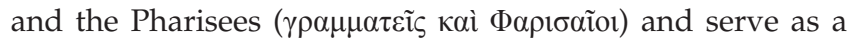

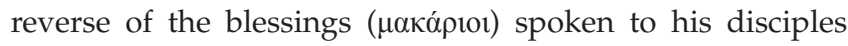
(oi $\mu \alpha \theta \eta \tau \alpha i ̀ ~ \alpha u ̉ \tau o \tilde{)}$ ) in Matthew 5:3-12.

This contrast between judgements and blessings resembles the similar contrast found in the repetitive recital of the Levites in Deuteronomy 27-28. The Levites should warn Israel not to transgress the commands and decrees given to them: 'Cursed is anyone who ...' (Dt 27:15-26). In contrast, blessings are recited for obedience to the commands of the Lord ('if you fully obey the Lord your God and carefully follow all his commands I give you today ...') (Dt 28:1) and 18.Cf. Isaiah $5: 8-23$ and Luke $11: 42-52$ each with its series of six woe-sayings. 
the result would be 'you will be blessed ...' (Dt 28:3-14). However:

if you do not obey the Lord your God and do not carefully follow all his commands and decrees I am giving you today, all these curses will come on you and overtake you ...'. (Dt 28:15)

This warning is confirmed by the Levites' repetitive recital of 'you will be cursed ...' (Dt 28:16-68) (Keener 2002:104). Jesus' addressees most likely would interpret Jesus' cursing of the Pharisees and teachers of the Law in terms of the curses in Deuteronomy. The conduct and teachings of the Pharisees and teachers of the Law would be understood as being untrue to the commands and decrees of the Lord.

The outcry, ov่aì (woe), combines the ideas of wrath and pain, and anger and sorrow (Bruner 2007:443; Esler 2015:50). While Jesus communicates salvation to his disciples with his

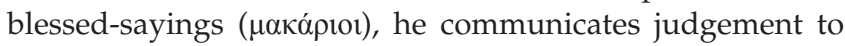
the teachers of the Law and the Pharisees with these woesayings (ovoi). As in Matthew 11:21, ${ }^{19}$ these woe-sayings express proleptic condemnation, anticipating the downfall of the Jewish religious leaders. Some parallels can be recognised between the seven 'woe-sayings' of Matthew 23:13-36 and the six of Luke 11:42-52. ${ }^{20}$ (see Figure 1)

The woe-sayings are composed of two parts: the addressees and their wrongs, while the judgements are heaped up at the end of the address (Mt 23:32-39) (Bruner 2007:442).

\section{Addressees of the woe-sayings}

Jesus' rejection of the teachers of the Law and the Pharisees is expressed in the manner he addresses them. The accusations in the Matthean version are much sharper and more extensive than in Luke. The Matthean Jesus repetitively charges them

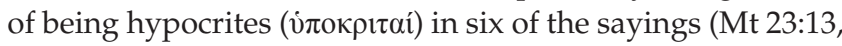

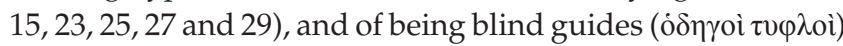
three times in the third saying (Mt 23:16), a charge that is repeated in the fourth (Mt 23:24) and fifth saying (Mt 23:26).

The Matthean Jesus in quite a number of instances does not hesitate to call the teachers of the Law and Pharisees hypocrites (e.g. Mt 6:2, 16; 15:7; 23:13, 15, 25, 29). In his address to the crowds, Jesus had already exposed the hypocritical conduct of these religious leaders. He criticised them for being hypocritical as they boast about their righteous accomplishments (cf. Mt 6:1-2). They act with ethical pretence by making people into spectators and trying to impress them to sustain their own status, as Jesus warns in Matthew 23:5-7 with respect to them parading their pious acts in public to gain praise. ${ }^{21}$

\section{Matthew 11:21: 'Woe to you, Korazin! Woe to you, Bethsaida! ...'}

20.Luke's second and fourth 'woe-sayings' to the Pharisees (Lk 11:43, 'Woe to you Pharisees, because you love the most important seats in the synagogues and respectful greetings in the marketplaces' and Luke 11:46, 'And you experts in the law, woe to you, because you load people down with burdens they can hardly carry, and you yourselves will not lift one finger to help them'), respectively, runs carry, and you yourselves will not lift one finger to help them'), respectively, runs
parallel to Jesus' address to the crowds (Mt 23:6-7 and Mt 23:4). Luke's third 'woesaying' (Lk 11:44) has no direct parallel in Matthew.

21.Such conduct was typical of the honour and shame society in which Jesus and his disciples lived, as one's good reputation was sustained by the esteem of others
As in Matthew 15:14, Jesus labels the teachers of the Law and

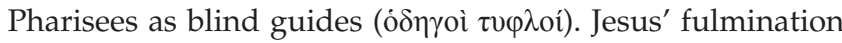
against blindness refers to their inability to distinguish between the important and unimportant emphases of the Scriptures (cf. Mt 23:17,22 19) ${ }^{23}$ (Bruner 2007:446). He therefore accuses them of false interpretation of the Law, their halakha, as they are blind guides who mislead their followers (Mt 23:24) (Powell 1995:432).

\section{Wrongs of the addressees}

The second part of each woe-saying expresses the wrong of the teachers of the Law and the Pharisees. The extent of Matthew's woe-sayings expresses the strong disapproval of the Matthean Jesus, not only of the conduct of the teachers of the Law and Pharisees but also of their teachings. The first three woe-sayings focus on the false teaching of the leaders (Mt 23:13-22), the next three mainly on their false practice (Mt 23:23-28), while the last saying accuses their false security as if they were not guilty of killing the prophets (Mt 23:29-36) (Bruner 2007:442) (see Table 5).

Woes for wrong teaching: The first three woe-sayings mainly denounce the wrong teachings (halakha) of the religious leaders.

The first saying (Mt 23:13-14) accuses them of shutting the door of the kingdom in people's faces. How they shut it is not explicitly mentioned, but it probably refers to the laying of heavy burdens on people's shoulders (Mt 23:4). Earlier in the text, Jesus reflected on the heavy yoke of complicated halakhic teachings and traditions (Mt 11:28-30). The parallel in Luke 11:52 mentions that they have taken away the keys of knowledge. This interpretation correlates with the assumed authority of the teachers of the Law and Pharisees, who sit on the seat of Moses (Mt 23:2). They were regarded as the custodians of the Torah, of God's will (Davies \& Allison 2004:267). In contrast with this accusation, Jesus has given Peter the keys of the kingdom (Mt 16:18), the one who has confessed Jesus to be the Christ, the Son of the living God (Mt 16:16).

The second saying (Mt 23:15), which does not have a parallel in Luke, continues the accusation of the first saying by describing the devastating effect of the teachers of the Law and the Pharisees on others. They who shut the kingdom of heaven in people's faces (Mt 23:13) are those who travel all around to make proselytes, ${ }^{24}$ but by doing so they prepare

(Carter 2000a:158; De Silva 2004:125; Malina \& Rohrbauch 2003:370; Witherington 2013:49). Jesus therefore opposes a fundamental societal pattern in which they participated.

22. Matthew 23:17: You blind fools! Which is greater: the gold, or the temple that makes the gold sacred?

23.Matthew 23:19: You blind men! Which is greater: the gift, or the altar that makes the gift sacred?

24.Rabbi Eleazar of Modiim says: 'God scattered Israel among the nations for the sole purpose that proselytes would be numerous among them' (b. Pesach. $87 \mathrm{~b})$. Though Pharisees did not have missionaries as such, Jewish people outside Palestine were eager to make converts of the Gentiles. It was said that Hillel was especially open to converting non-Jews to Judaism (Keener 2002:104). Nevertheless, the emphasis does not lie in the missionary activity of the Pharisees but on the irony of the fact that their efforts result in disastrous results (Gundry 1994:461). 


\section{Judgement for closing the kingdom for others (Mt 23:13)}

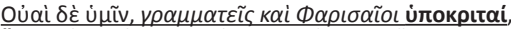

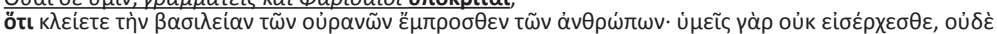

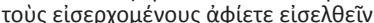

(Woe to you, teachers of the Law and Pharisees, you hypocrites!

You shut the door of the kingdom of heaven in people's faces. You yourselves do not enter, nor will you let those enter who are trying to)

\section{Judgement for leading proselytes to hell (Mt 23:15)}

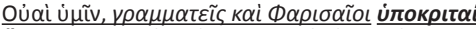

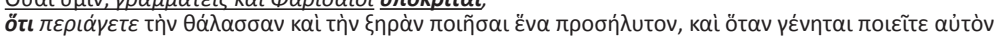

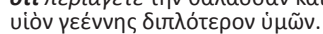

(Woe to you, teachers of the Law and Pharisees, you hypocrites!

You travel over land and sea to win a single convert, and when you have succeeded, you make them twice as much a child of hell as you are)

3. Judgement for false teaching on swearing (Mt 23:16-22)

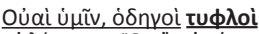

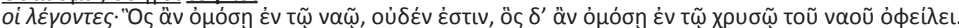

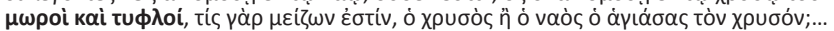

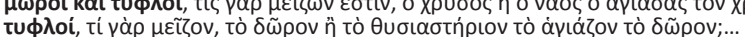

(Woe to you, blind guides!

You say, 'If anyone swears by the temple, it means nothing; but anyone who swears by the gold of the temple is bound by that oath.

You blind fools! Which is greater: the gold, or the temple that makes the gold sacred? ...

You blind men! Which is greater: the gift, or the altar that makes the gift sacred? ...)

4. Judgement for meticulous tithing while being merciless (Mt 23:23-24)

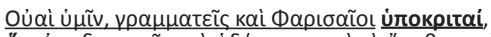

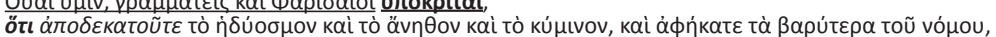

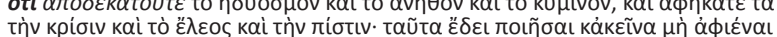

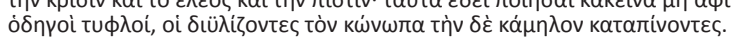

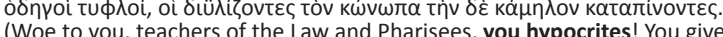

(Woe to you, teachers of the Law and Pharisees, you hypocrites! You give a tenth of your spices -

mint, dill and cumin. But you have neglected the more important matters of the law - justice, mercy and faithfulness. You should have practiced the latter, without neglecting the former

You blind guides! You strain out a gnat but swallow a camel)

5. Judgement for ritual cleanness yet unclean hearts (Mt 23:25-26)

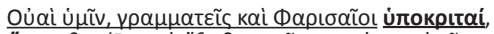

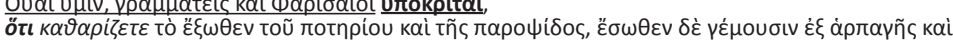
ákрабíą.

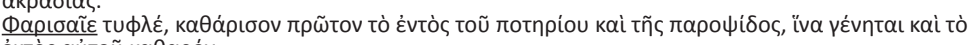

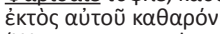

(Woe to you, teachers of the Law and Pharisees, you hypocrites

You clean the outside of the cup and dish, but inside they are full of greed and self-indulgence.

Blind Pharisee! First clean the inside of the cup and dish, and then the outside also will be clean)

\section{Judgement for external self-righteousness yet wicked interior (Mt 23:27-28)}

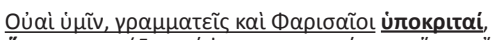

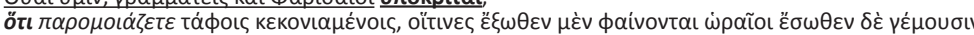

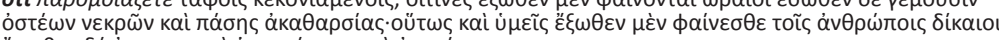

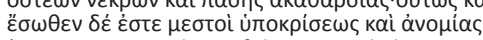

(Woe to you, teachers of the Law and Pharisees, you hypocrites!

You are like whitewashed tombs, which look beautiful on the outside but on the inside are full of the bones of the dead and everything unclean. In the same way, on the outside you appear to people as righteous but on the inside you are full of hypocrisy and wickedness)

7. Judgement for participating in the sins of their ancestors (Mt 23:29-32)

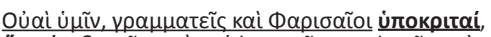

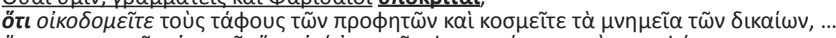

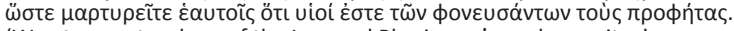

(Woe to you, teachers of the Law and Pharisees, $\uparrow$ you hypocrites!

You build tombs for the prophets and decorate the graves of the righteous,

So you testify against yourselves that you are the descendants of those who murdered the

prophets ...)
Judgement for closing the kingdom for others - Luke's sixth woe-saying

(Lk 11:52)

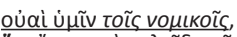

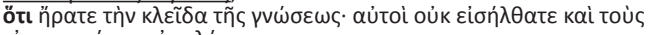

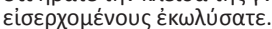

(Woe to you experts in the law, because you have taken away the key to knowledge. You yourselves have not entered, and you have hindered those who were entering.)
Judgement for meticulous tithing while being merciless - Luke's first woe-saying (Lk 11:42)

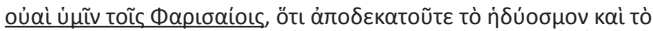

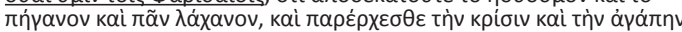

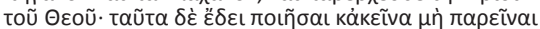

Woe to you Pharisees, because you give God a tenth of your mint, rue and all other kinds of garden herbs, but you neglect justice an the love of God. You should have practiced the latter without leaving the former undone.

Judgement for ritual cleanness yet unclean hearts; though without the use of oúai újũv of a formal woe-saying (Lk 11:39-40)

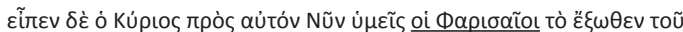

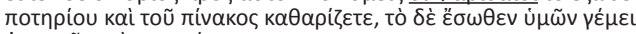

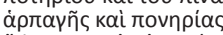

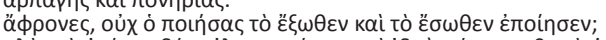

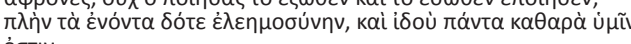
ह̇øtı.

Now then, you Pharisees clean the outside of the cup and dish, but inside you are full of greed and wickedness.

You foolish people! Did not the one who made the outside make the inside also? But now as for what is inside you - be generous to the poor, and everything will be clean for you.

\footnotetext{
$\dagger$, With the exception of Matthew 27:62, this is the last mention of the Pharisees in Matthew. They leave the stage in disgrace under looming judgement (Davies \& Allison 2004:304).
}

FIGURE 1: Parallels between the 'woe-sayings' in Matthew and Luke.

Table 5: Woes for the wrong teachings and conduct of the teachers of the Law and Pharisees.

\begin{tabular}{ll}
\hline Woes for wrong teachings & Woes for wrong conduct \\
\hline $\begin{array}{l}\text { Shutting the door of the kingdom of } \\
\text { heaven in people's faces (Mt 23:13) } \dagger\end{array}$ & $\begin{array}{l}\text { Meticulous tithing while being merciless } \\
\text { (Mt 23:23-24) } \$\end{array}$ \\
$\begin{array}{l}\text { Proselyting using false teaching } \\
\text { (Mt 23:15) }\end{array}$ & $\begin{array}{l}\text { Ritual cleanness yet unclean hearts } \\
\text { (Mt 23:25-26) }\end{array}$ \\
False teachings on swearing (Mt 23:22) & $\begin{array}{l}\text { External self-righteousness yet with } \\
\text { wicked interior (Mt 23:27-28) }\end{array}$ \\
\hline
\end{tabular}

$\dagger$, The Lukan parallel reads: 'you have taken away the key to knowledge' (Lk 11:52).

$\$$, The Lukan parallel woes the neglect of justice and the love of God (Lk 11:42) people for hell (Mt 23:15). The proselytes were convinced by the teachings of the teachers of the Law and the Pharisees, and thus became severe opponents of the teachings of Jesus (Bruner 2007:444).

The third saying (Mt 23:16-22), which also lacks a parallel in Luke, accuses the complicated teachings of the Jewish religious leaders on swearing. This woe resembles Matthew 5:33-37 with its critique on halakha, which proposes a 
distinction between binding and non-binding oaths (Davies \& Allison 2004:290). The Matthean Jesus lists a series of variant forms of swearing as proposed by the Pharisees in parallel statements (Gundry 1994:462). By replacing the divine name with lesser ranking substitutes, they regard the oaths as less serious (Keener 2002:104).

Woes for wrong conduct: The next three woes mainly focus on the wrong conduct of the teachers of the Law and the Pharisees.

The third (Mt 23:16-22), fourth (Mt 23:23-24) and the fifth woes (Mt 23:25-26) are bound together with reference to

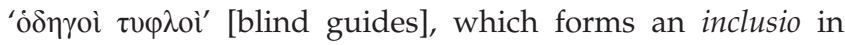
Matthew 23:16 and 24. In the fourth woe, Jesus accuses his addressees of meticulous attention to ceremonial cleanliness and external devotions of piety, but then neglecting more important issues. Though Jesus primarily refers to their wrong conduct, he accuses them of misleading others with their halakha as they are 'ó $\delta \gamma$ oi $\tau v \varphi \lambda$ oi' [blind guides] (Davies \& Allison 2004:293). France (2007:870) remarks: 'The basis of Jesus' criticism is that the scribal approach is superficial, and fails to think through the principles underlying the details on which their debate is focussed'. Once again, Jesus criticises their presumed teaching authority. Jesus uses the humorous hyperbole of 'straining out a gnat, but then swallowing a camel $^{25}$ (Mt 23:24) to drive the point. While the tithing of mint, dill and cumin was not required by the Law, they neglected justice, mercy and faithfulness. The Matthean Jesus more than once emphasises the importance of justice, mercy and covenantal faithfulness (Mt 9:13; 12:7) (Keener 2002:105). This accusation against the Pharisees and teachers of the Law continues Jesus' argument of Matthew 15:3-9. ${ }^{26}$

The fifth saying (Mt 23:25-26) adds to the charge of the fourth saying of doing the less important things, while neglecting the more important ones. The teachers of the Law and the Pharisees clean the outside of their cups and dishes but not their insides. Jesus uses this as a figurative statement about the inside of the hearts (Davies \& Allison 2004:296; Keener 2002:105). On the outside, the addressees propose to be righteous but in the inside they are full of greed and indulgence. Jesus carries forward the theme of the Sermon on the Mount where he states that one's inner attitude determines

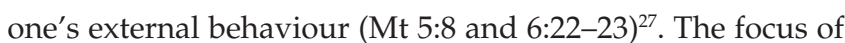
morality should be one's heart, which is not the case with his addressees (Gundry 1994:465).

In the sixth saying (Mt 23:27-28), the topic continues. The fifth and sixth woes are bound together by the common contrast between inside and outside (Mt 23:25-28). Jesus figuratively refers to whitewashed tombs full of dead men's bones and everything unclean. Nothing spread ritual 25.Camels were the largest animals in Palestine and also ritually unclean (Lv 11:4).

26.'And why do you break the command of God for the sake of your tradition? ...' (Mt 15:3-9).

27.'Blessed are the pure in heart ...' (Mt 5:8) and '.. If then the light within you is darkness, how great is that darkness!' (Mt 6:22-23). impurity as severely as a corpse, ${ }^{28}$ as one who touched a corpse was unclean for a week (Nm 19:11) (Keener 2002:105). Matthew's emphasis lies on the hiding of inward corruption, as the washing symbolises the hypocrisy of the Pharisees (Gundry 1994:466). While teachers of the Law and Pharisees are pretentiously preoccupied with matters of external purity and outer appearance, their inner beings are accused of being sources of severe impurity (Davies \& Allison 2004:302).

Woe for false security: In the seventh saying (Mt 23:29-32), the Matthean Jesus exposes the contrast between their confession and conduct, which provides a clear illustration of their hypocrisy. Jesus accuses them of a gulf between their words and deeds, being the essence of hypocrisy (Gundry 1994:468). While they are descendants of those forefathers who abhorred the prophets, they now honour the same prophets by erecting tombs and elaborate monuments for them. Jeremiah 26:20-23 and 2 Chronicles 36:15-16 describe how Israel had martyred its prophets and Jesus argues that corporate guilt continued among descendants. Jesus closes with an ironic challenge to proceed with their $\sin , \pi \lambda \eta \rho \omega ́ \sigma \alpha \tau \varepsilon$

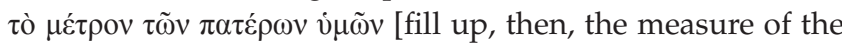
sin of your forefathers] (Mt 23:32), but God will judge them (Keener 2002:105). Filling up the measure of the sin probably not only refers to the building of the tombs, but like their forefathers, they were about to murder yet another prophet, this time Jesus and his followers (Gundry 1994:468).

\section{Judgement (Mt 23:33-36)}

The sinful conduct of the addressees leads towards eschatological judgement. The teachers of the Law and Pharisees are labelled as snakes and the charge is doubled, as they are also labelled as offspring of vipers (ö $\varphi \varepsilon 1 \varsigma, \gamma \varepsilon v v \eta \dot{\mu} \mu \tau \alpha$ Ė $\chi 1 \delta v \tilde{\omega} v)\left(\right.$ Mt 23:33) ${ }^{29}$ (Gundry 1994:469). ${ }^{30}$

According to the Matthean Jesus, the conduct of the teachers of the Law and the Pharisees resemble the rejection of the prophets in the days of Zechariah. This passage seems to be based on 2 Chronicles 24:17-22, 25 using the historical language of the Chronicles and applying it to the time of Jesus. The analogy lies in what had happened in the days of Zechariah, would again happen in the days of Jesus (Davies \& Allison 2004:318). The prophets were rejected in the times of Zechariah and so again Jesus and his disciples would be rejected as the prophets of God. The teachers of the Law and Pharisees would deliver Jesus and his disciples to be crucified $^{31}$ and would flog them in their synagogues (Mt 23:34).

28.Pharisees presumably believed that even if one's shadow touched a corpse or a grave, one would become impure (Keener 2002:105).

29.A similar train of thought appears earlier in the gospel when John the Baptist also calls the Pharisees and Sadducees offspring of vipers, though they claim to have Abraham as their father (Mt 3:7b-9).

30.According to Keener (2002:105), to be labelled a venomous snake is bad, but it is even worse to be labelled offspring of vipers, as vipers presumably were notorious for eating their way out of their pregnant mothers' bellies.

31.Crucifixion was the most severe punishment, reserved for non-Romans. Jews who would deliver fellow Jews for crucifixion obviously were despised by fellow Jews. Flogging in synagogues was a form of discipline for errant members (Keener 2002:106) 
The result is that all the righteous blood that has been shed on earth would come upon them (ö $\pi \omega \varsigma$ हैं $\lambda \theta \eta \underline{\varepsilon} \dot{\varepsilon} \varphi$ ' $\dot{\mu} \mu \tilde{\alpha} \varsigma \pi \tilde{\alpha} \nu \alpha \tilde{i} \mu \alpha$

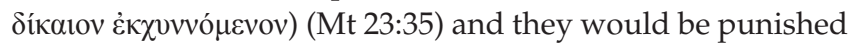

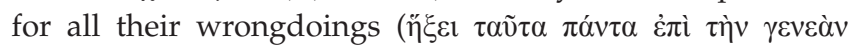

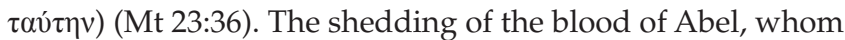
the Jews regarded as the first martyr (Gn 4:8), and that of Zechariah, whom the Jews regarded as the last martyr (2 Chr 24:22), is mentioned (Gundry 1994:471; Keener 2002:106; Simmonds 2009:346). Zechariah explicitly prayed for judgement. According to Jesus, the judgement from the first to the last martyr is saved for this wicked generation.

\section{Addressing Jerusalem with sorrow and lament (Mt 23:37-39)}

The chapter is concluded with a lament addressing Jerusalem. Jesus uses the well-known image of God's love for his people, namely, of protecting them under his wings (Ps 17:8; 46:7; $57: 1 ; 61: 4 ; 63: 7 ; 91: 4)$. Converted gentiles were also brought under the protecting wings of God's presence (Rt 2:12). Jesus applies this image to demonstrate his efforts to take care of

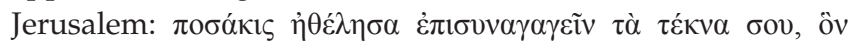

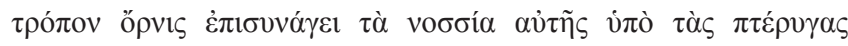
(Keener 2002:106). However, Jerusalem rejected his loving

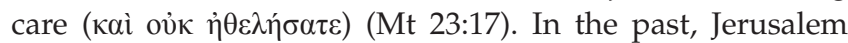
forsook the Lord, and he therefore forsook the city. He withdrew his divine presence. Now Jerusalem forsakes Jesus, and the city and the temple will therefore be forsaken.

\section{Conclusion}

Considering the intra-textual setting of Matthew 23:3, it is clear that the Matthean Jesus is critical of the conduct and the teaching of the teachers of the Law and the Pharisees. While the sentiment towards these leaders is negative throughout the gospel, the conflict clearly intensifies and culminates in Jesus' extensive criticism in Matthew 23. First, Jesus addresses the crowds, warning them of the insincerity of these Jewish leaders. Their conduct is hypocritical and their teachings are misleading. He pronounces a series of woes in which he accuses them of being hypocritical and spiritually blind. He bemoans the destiny of Jerusalem, which as in the days of Zechariah will be desolate as this city has opposed and killed the true prophets of God.

When Jesus instructs the crowds to obey the teachers of the Law and the Pharisees in everything they tell them (Mt 23:3a), he does this in the context of accusing them of having a skewed understanding of the Torah and of doing something wrong. The suggestion of Gundry and Powell is possible, that Jesus only refers positively to their precise citing of the written Torah but criticises their interpretation (halakha) of it. When Jesus proceeds to illustrate his statement later on, it is clear that he accuses both the teachers of the Law and the Pharisees of wrong teachings and hypocritical conduct. However, it seems more probable that Jesus makes this surprising instruction in an ironic way to sternly expose the paradox with the Jewish leaders, as saying the one, but doing the other. The overall sentiment towards them remains negative.

\section{Acknowledgements}

The author thanks the National Research Foundation of South Africa (NRF) for providing funding for this study. The views expressed do not necessarily reflect the view of the NRF.

\section{Competing interests}

The author declares that he has no financial or personal relationships which may have inappropriately influenced him in writing this article.

\section{References}

Bruner, F.D., 2007, Matthew, a commentary, volume 2: The Churchbook Matthew 13-28, William Eerdmans, Grand Rapids, MI.

Carter, W., 2000a, Matthew and the margins. A socio-political reading, Academic Press, Sheffield. (Journal for the Study of the New Testament, Supplement Series 204)

Carter, W., 2000b, 'Matthew 23:37-39', Interpretation 54(1), 66-68. https://doi.org/ $10.1177 / 002096430005400110$

Combrink, H.J.B., 1983, 'The structure of the Gospel of Matthew as narrative', Tyndale Bulletin 34, 61-90.

Davies, W.D. \& Allison, D.C., 2004, Matthew 19-28, International Critical Commentary, vol. 3, T. \& T. Clark, London \& New York.

Deines, R., 2008, 'Not the Law but the Messiah: Law and Righteousness in the Gospel of Matthew - An ongoing debate', in D.M. Gurtner \& J. Nolland (eds.),
Built upon the Rock. Studies in the Gospel of Matthew, pp.53-84, Eerdmans, Built upon the Rock.
Grand Rapids, MI.

De Silva, D.A., 2004, An introduction to the New Testament; contents, methods and ministry formation, IVP Academic, Downers Grove, IL.

Esler, P.F., 2015, 'Intergroup conflict and Matthew 23: Towards responsible historical interpretation of a challenging text', Biblical Theology Bulletin 45(1), 38-95. https://doi.org/10.1177/0146107914564824

France, R.T., 2007, The Gospel of Matthew, William B. Eerdmans Publishing Company, Grand Rapids, MI.

Gundry, R.H., 1994, Matthew; A commentary on his handbook for a mixed church under persecution, Eerdmans, Grand Rapids, MI.

Hagner, D.A., 1993, Matthew 1-13, Word Books, Dallas, TX. (Word Biblical Commentary 33A).

Keener, G.S., 1999, A commentary on the Gospel of Matthew, Eerdmans, Grand Rapids, MI.

Keener, G.S., 2002, The IVP Bible Background Commentary; New Testament, IVP Academic, Downers Grove, IL.

Kingsbury, J.D., 1995, 'The developing conflict between Jesus and the Jewish leaders in Matthew's Gospel: A literary-Critical study', in G. Stanton (ed.), The interpretation of Matthew, pp. 179-197, T \& T Clark, Edinburgh.

Kümmel, W.G., 1967. 'Die Weherufe über die Schriftgelehrten un Pharisäer (Matthäus 23,13-36)', in W.P. Eckert (ed.), Antijudaismus in Neuen Testament? pp. 135-147, Kaiser Verlag, München.

Luz, U., 1968, The Synoptic Gospels, Ktav, New York.

Malina, B.J. \& Rohrbauch, R.L., 2003, Social-science commentary on the Synoptic Gospels, Fortress Press, Minneapolis, MN.

Mason, S., 1990. 'Pharisaic dominance before $70 \mathrm{CE}$ and the Gospels' hypocrisy charge (Matt. 23:2-3)', Harvard Theological Review 83, 363-381. https://doi. org/10.1017/S0017816000023841

Newport, K.G.C., 1995, The sources and Sitz im Leben of Matthew 23, JSNTSup 117, Academic Press, Sheffield.

Oliver, I.W., 2013, Torah praxis after 70CE; reading Matthew and Luke-Acts as Jewish texts, Mohr Siebeck, Tübingen.

Osborne, G.R., 2010, Matthew, Zondervan, Grand Rapids, MI. (Zondervan exegetical commentary on the New Testament).

Powell, M.A., 1995. 'Do and keep what Moses says (Matthew 23:2-7)', Journal of Biblical Literature 114(3), 419-435. https://doi.org/10.2307/3266261

Rabbinowitz, N.S., 2003. 'Matthew 23:2-4: Does Jesus recognize the authority of the Pharisees and does He endorse their halakhah?', Journal of the Evangelical Theological Society 46(3), 423-447.

Repschinski, B., 2000, The controversy stories in the Gospel of Matthew: Their redaction, form and relevance for the relationship between the Matthean community and formative Judaism, Vandenhoeck \& Ruprecht, Göttingen.

Riesner, R., 1978, 'Der Aufbau der Reden im Matthäus-Evangelium', Theologische Beiträge 9, 177-178.

Simmonds, A.R., 2009, "“Woe to you ... hypocrites!” Re-reading Matthew 23:13-36', Bibliotheca Sacra 166, 336-349. 
Talbert, C.H., 2010, Matthew, Baker Academic, Grand Rapids, MI. (Paideia commentaries on the New Testament).

Viljoen, F.P., 2013, 'Jesus' halakhic argumentation on the true intention of the law in Matthew 5:21-48', Verbum et Ecclesia 34(1), 1-12.

Viljoen, F.P., 2014,'External cultic tradition and internal ethical purity in Matthew 15', In Luce Verbi 48(1), 1-12.
Viviano, B.T., 1990, 'Social word and community leadership: The case of Matthew 23:1-12, 34', JSNT 39, 3-21.

Wiefel, W., 1998, Das Evangelium nach Matthäus, Theologischer HandKommentar zum Neuen Testament, I, Evangelische Verlagsanstalt, Leipzig.

Witherington, B., 2013, Invitation to the New Testament; First things, University Press, Oxford. 